\title{
Small Farms and Agricultural Productivity-A Macro Analysis
}

\author{
R. G. Kadapatti ${ }^{1} \&$ S. T. Bagalkoti ${ }^{2}$ \\ ${ }^{1}$ Research Scholar, Department of Studies in Economics, Karnatak University, Dharwad, India \\ ${ }^{2}$ Faculty, Department of Studies in Economics, Karnatak University, Dharwad, India \\ Correspondence: R. G. Kadapatti, Research Scholar, Teacher Fellow on FIP, Department of Studies in Economics, \\ Karnatak University, Dharwad
}

Received: June 23, 2014

Accepted: June 30, $2014 \quad$ Available online: July 9, 2014

doi:10.11114/ijsss.v2i3.463

URL: http://dx.doi.org/10.11114/ijsss.v2i3.463

\begin{abstract}
Small farms measuring less than 2 hectares constitute $85 \%$ of the total operated farms in the world. Overwhelming majority of these small farms are located in Asia (87\%) followed by Africa (8\%) and Europe (4\%). In Asia, China accounts for half of the world's small farms (193) followed by India. Global trends indicate a decline in small farms in developed countries, while there is an increase in small farms in developing countries. Average farm size in Asia and Africa is 1.6 hectare compared to 67 hectares in Latin America, 27 hectares in Europe and 121 hectares in North America. Various studies in India during the $60 \mathrm{~s}, 70 \mathrm{~s}$ and in the later years have revealed that there is an inverse relationship between size of farms and productivity, despite a few researchers holdings contrary opinion. Findings by UN agencies and National Sample Survey (NSS) have supported farm size and productivity relationship.

Small farms have been the main stay for food security and labour employment in India. Despite their significance in providing food security, family labour employment and economy in management and high productivity per acre, small farms face a few challenges particularly in the wake of globalisation and WTO dispensation. Enhancing the productivity of small farms has been stressed by various experts. Measures like providing modern technology, information and knowledge for better skills and extended credit have been suggested for higher productivity of small farms. Small farms need positive material and policy support by the Government.
\end{abstract}

Keywords: Small farms, operational area, operational holdings, Average size, Agricultural Productivity, Cropping Intensity, Diversification \& Livelihood.

\section{Introduction}

There are serious concerns about the performance of agricultural sector in India. Agricultural sector has shown less than 2 percent per annum growth during the past decade. Further there is disconnection between employment growth and GDP growth. There has been a lopsided approach to agriculture in India during the last few decades.

Globalisation policies during the 1980s and particularly during1990s and beyond have created many challenges for Indian agriculture. Some of the consequences and impacts of globalisation relate to i) exposure of domestic agriculture to international competition ii) growth of non-agricultural sector and its impact on demand for agricultural products iii) Urban middleclass lifestyle changes including diet, rising food imports, competitiveness and diversification of domestic production system iv) Vertical integration of food supply chain etc.

The small farmers have to face these problems in the post WTO dispensation. The paper tries to analyse the various aspects of small farm holdings, their strengths, the challenges faced by them and the opportunities available for their future growth etc.

\section{Objectives}

The research paper has the following objectives:

1) To provide a comprehensive conceptual frame work for the small farm holdings.

2) To analyse the broad trends of small farm holdings at global, national and regional level.

3) To discuss the different aspects of strength, constraint and challenges of small farms.

\section{The Current Study}

The relationship between size and farm productivity has been discussed intensively by experts based on their research 
findings. Size and productivity are related inversely according to some researchers who attribute it to intensive cultivation with reduced cost of farm inputs and by using family labour. Large farms on the other hand involve greater amount of inputs and more manpower. It results in more operational time, more resource costs and investment in farm infrastructure. Small farms involve cost economies due to use of family labour and lesser involvement of inputs and infrastructure. A large number of studies during 1960s and 1970s have provided convincing evidence that crop productivity per unit of land declined with an increase in farm size (Sen 1962, 1964, Muzumdar 1965, Khusro 1968, Hanumanth Rao 1966, Saini 1971, Bardhan 1973 and Berry 1972). Their arguments were advanced for supporting land reforms, land ceiling and other policies to support small holders on grounds of cost economy, efficiency and growth.

Some recent studies too have affirmed the superiority of small farms particularly in the Indian context, Vandana Shiva (2007) has highlighted the significant role of small farmers who provide food security for one billion people as 80 percent of farmers own less than 2 hectares of land. She has reflected the claim that small farms have limitations in improving agricultural productivity. Small bio-diverse farms have higher productivity than monocultures which are necessary aspects of industrial agriculture based on external inputs. She has rightly cited the examples of how higher biological productivity translates into higher incomes for small farmers. The examples of Pearl Millet in Rajasthan and other experiments in Uttaranchal and Sikkim have been cited.

A UN report has been cited by Robert Evans (2011), in favour of small farms with better productivity. "Evidence has shown that for most crops of the optimal farm is small in scale and that is at this level that most gain in terms of both sustainable productivity increases and rural poverty reduction can be achieved". The thrust of the UN Report is that Governments must work towards a major shift towards small scale farming if endemic food crisis are to be overcome and production boosted to support the global population. The NSS data has been cited in favour of small farms having higher productivity (Chand Ramesh et al., 2011). Small holdings in Indian agriculture still exhibit a higher productivity than large holdings.

Small holdings have been found to exhibit many advantages as indicated by some in the Indian context. Some of the favourable and strong points of small holdings compared to the larger ones are worth noting.

\section{The Method}

The study is macro analysis of small farms and agricultural productivity in the Indian context. The data is obtained through secondary sources and the analysis is based on secondary data. The data is obtained from published sources. The reports of Agricultural Census during 1976-77 to 210-11 and Input Survey during 1976-77 to 2006-07 published by Government of India are major sources of data. Report of NSS $59^{\text {th }}$ Round on Situation Assessment Survey of Farmers published by Government of India, publications of IFPRI, IFAD, World Bank, The Journal of Political Economy, The Economic and Political Weekly, etc have also been the other sources of secondary data and literature related to the study.

The Government of India conducts Agricultural Census from 1970-71 and Input Survey from 1976-77 for every five years. But, to study the decadal changes of different aspects of agricultural holdings viz., size of farms, nature of farms, land use, usage os inputs, cropping intensity etc and their impact on agricultural productivity, and for comparative analysis of those elements, the reports of Agricultural Census of 1976-77, 1985-86, 1985-96, 2005-06 and 2010-11; the reports of Input Survey of 1976-77, 1986-87, 1996-97 and 2006-07 are selected. The statistical tools like growth rates and percentages have been used for analysis and interpretation of the data.

\section{Findings}

\subsection{The Conceptual Framework of Small Farms}

The conceptual approach to small farms is made from a variety of angles. Small scale farming is often used interchangeably with small holders-family-subsistence- resource poor-low income-low input or low technology farming. The following approaches indicate the diversity of the concept of small farming.

1) Family farms are operated units in which most labour and enterprise come from family which puts much of its working time in the farm (Lipton 2005).

2) Small holders are those with a low asset base operating less than 2 hectares of crop land (World Bank 2003).

3) Small farmers are those with limited resource endowments relative to other farmers in the sector.(Dixon, et al 2003).

4) A smallholder is a farmer practicing a mix of commercial and subsistence production or either where the family provides the majority of labour and the farm provides the principal source of income.(Narayan and Gulati 2002). 
5) Small farms as those depending on household members for most of the labour or those with a subsistence orientation, where the primary aim of the farm is to produce the bulk of the households consumption of staple food (Hazell et al., 2007).

The above approaches indicate a lack of unanimity about the concept of small farms. It is however the most common measure to categorise small farms by number of international reports viz., IFPRI, IFAD, FAO etc., and national reports like Agricultural Census reports and Input Survey reports of GOI, the reports of RBI and planning commission etc., is that small farms and small holders are those farms of less than 2 hectares of owned or rented land. It is also assumed that the small farm family provides the primary source of labour and that farming constitutes a principal source of income to the family.

\subsection{Dimensions of small Farms-Global and Regional Scenario}

There are approximately 500 million small farms. They constitute 85 percent of the total farms. The overwhelming majority of these farms are located in Asia viz., 87\% (IFPRI 2007) while Africa is for home another 8\%, and Europe to approximately 4\%. In Asia, China alone accounts for almost half the worlds small farms (193 million) followed by India with 117 million (23\%). Others in the region are in descending order they include Indonesia, Bangladesh and Vietnam.

\subsubsection{Trends in Farm size-Global view}

Global trends indicate divergent movement in the direction of size farm holdings in developing and developed countries. In the developing countries small farmers dominate the agricultural landscape especially in Africa and Asia for at least the next two to three decades. Historical trends from developed countries show that the size of farms increased during the second half of the $20^{\text {th }}$ century while the number of small farms decreased.

Table 1. Approximate farm size by World/Region

\begin{tabular}{ll}
\hline World/Region & Average farm size (hectares) \\
\hline Africa & 1.6 \\
Asia & 1.6 \\
Latin America & 67 \\
Western Europe & 27 \\
North America & 121 \\
\hline
\end{tabular}

Source: Von Braun 2005, IFPRI

As shown in the above Table 1, United States average farm size has grown from 157 hectares in 1969 to 179 hectares in 2002, peaking at almost 200 hectares in the mid 1990s. Similar trends can be observed in the United Kingdom, where the average farm size grew from 55 to 70 hectares during 1970-93. Farm size in North America currently averages 121 hectares and in Western Europe it averages 27 hectares.

5.2.2 Structural changes in Landholdings of India

Table 2. Trends in Number, Operated area and Average size of holdings in India

\begin{tabular}{cccc}
\hline Year & Number of holdings $\left(\mathrm{mn}^{*}\right)$ & $\begin{array}{c}\text { Area operated } \\
(\text { in mn ha })\end{array}$ & $\begin{array}{c}\text { Average area per } \\
\text { holding (in ha* }\end{array}$ \\
\hline $1976-77$ & 81.60 & 163.34 & 2.00 \\
$1985-86$ & 97.20 & 164.56 & 1.69 \\
$1995-96$ & 115.60 & 163.36 & 1.41 \\
$2005-06$ & 129.22 & 158.32 & 1.23 \\
2010-11 & 138.35 & 159.59 & 1.15 \\
\hline \% variation during 1976-77 to & 69.55 & -2.30 & \\
2010-11 & 1.99 & -0.07 & \\
\hline Annual growth rate & &
\end{tabular}

*mn: million ha: Hectare

Source: GOI, Agricultural Census Reports from 1976-77 to 2010-11, All India Report on Number and Area of Operational Holdings, Agricultural Census Division, Department of Agricultural and Co-operation, Government of India, New Delhi 
Table 2 shows the number, operational area and average size of land holdings in India during 1976-77 to 2010-11. The total number of operational land holdings in India has increased from 81.60 $\mathrm{mn}$ in 1976-77 to $138.35 \mathrm{mn}$ in $2010-11$ shows $69.55 \%$ increase in total number of holdings with the average annual growth rate $1.99 \%$ during 35 years.

During the same period there is marginal decrease in operational area of land holdings in India from 163.34 mnhectare (ha) in 1976-77 to $159.59 \mathrm{mn}$ he in 2010-11. Shows $3.75 \%$ decrease in operational area with the average annual growth rate $-0.07 \%$. But the operated area has increased from $158.32 \mathrm{mn}$ ha to $159.59 \mathrm{mn}$ ha. 2005-06 to $2010-11$ census shows an increase of $0.80 \%$. It is because the State of Jharkhand participated for the first time in Agricultural Census of 2010-11.

Compared to the trend in number and area of operational holdings it is found that there is sharp increase in number of holdings and gradual increase in area of operational holdings during 1976-77 to 2010-11. Therefore, the average area per holding in India is decreasing and it has decreased from 2.00 to 1.15 ha during 1976-77to 2010-11.

Table 3.Trends in number of different size of holdings in India

\begin{tabular}{|c|c|c|c|c|c|c|c|}
\hline \multirow{2}{*}{ Size groups } & \multicolumn{5}{|c|}{ Number of Holdings ( in '000) } & \multirow{2}{*}{$\begin{array}{c}\text { Annual } \\
\text { growth rate }\end{array}$} & \multirow{2}{*}{$\begin{array}{l}\% \text { variation during } \\
1976-77 \text { to } 2010-11\end{array}$} \\
\hline & $1976-77$ & $1985-86$ & $1995-06$ & $2005-06$ & $2010-11$ & & \\
\hline \multirow{2}{*}{ Small } & 59251 & 74069 & 92822 & 107624 & 117605 & \multirow{2}{*}{2.81} & \multirow{2}{*}{98.49} \\
\hline & 72.64 & 76.64 & 80.31 & 83.29 & 85.01 & & \\
\hline \multirow{2}{*}{ Medium } & 19878 & 21168 & 21353 & 20502 & 19771 & \multirow{2}{*}{-0.02} & \multirow{2}{*}{-0.54} \\
\hline & 24.37 & 21.79 & 18.47 & 15.87 & 14.29 & & \\
\hline \multirow{2}{*}{ Large } & 2440 & 1918 & 1404 & 1096 & 973 & \multirow{2}{*}{-1.72} & \multirow{2}{*}{-60.12} \\
\hline & 2.99 & 1.97 & 1.21 & 0.85 & 0.70 & & \\
\hline \multirow{2}{*}{ All sizes } & 81569 & 97155 & 115580 & 129222 & 138348 & \multirow{2}{*}{1.99} & \multirow{2}{*}{69.61} \\
\hline & 100 & 100 & 100 & 100 & 100 & & \\
\hline
\end{tabular}

Source: GOI, Agricultural Census Reports from 1976-77 to 2010-11, Ibid

From the Table 3 it is seen that India has 117605 thousand small holdings in 2010-11 which got increased to 59251 thousand in 1976-77. The share of small holdings in total number of operational holdings in India was $72.64 \%$ in 1976-77 and increased to $85.01 \%$ in $2010-11$ which shows $98.49 \%$ increase in number of small holdings with annual growth rate of $2.81 \%$.

There is decline in the number of medium and large holdings in the country. The medium holdings got decreased from 19878 thousand in 1976-77 to 19771 thousand in 2010-11. The percentage of these holdings has decreased from $24.37 \%$ to $14.29 \%$ which reveals- $0.54 \%$ decrease with annual growth rate of $-0.02 \%$ during the same period.

Table 4. Trends in operated area of different size of holdings in India

\begin{tabular}{|c|c|c|c|c|c|c|c|}
\hline \multirow{2}{*}{ Size groups } & \multicolumn{5}{|c|}{ Operated Area ( in '000 ha) } & \multirow{2}{*}{$\begin{array}{l}\text { Annual } \\
\text { growth } \\
\text { rate }\end{array}$} & \multirow{2}{*}{$\begin{array}{c}\text { \% variation } \\
\text { during } \\
1976-77 \text { to } \\
2010-11\end{array}$} \\
\hline & $1976-77$ & $1985-86$ & $1995-06$ & $2005-06$ & $2010-11$ & & \\
\hline \multirow{2}{*}{ Small } & 38414 & 47750 & 58843 & 65127 & 71152 & \multirow{2}{*}{2.43} & \multirow{2}{*}{85.22} \\
\hline & 23.52 & 29.02 & 36.02 & 41.14 & 44.58 & & \\
\hline \multirow{2}{*}{ Medium } & 82056 & 83810 & 80351 & 74481 & 71533 & \multirow{2}{*}{-0.37} & \multirow{2}{*}{-12.82} \\
\hline & 50.24 & 50.93 & 49.19 & 47.04 & 44.82 & & \\
\hline \multirow{2}{*}{ Large } & 42873 & 33002 & 24161 & 18715 & 16907 & \multirow{2}{*}{-1.73} & \multirow{2}{*}{-60.56} \\
\hline & 26.25 & 20.05 & 14.79 & 11.82 & 10.59 & & \\
\hline \multirow{2}{*}{ All sizes } & 163343 & 164562 & 163355 & 158323 & 159592 & \multirow{2}{*}{-0.07} & \multirow{2}{*}{-2.30} \\
\hline & 100 & 100 & 100 & 100 & 100 & & \\
\hline
\end{tabular}

Source: GOI, Agricultural Census Reports from 1976-77 to 2010-11, Ibid

As regards to the operational area of land holdings among different size of land holdings in India it is shown in Table 4 that in total of 1,59,592 thousand hectare of operational area in the country, the small holdings formed a share of $23.52 \%$ in 1976-77 which increased to $44.58 \%$ in $2010-11$ i.e., due to increase in operational area belongings of small holdings 38414 thousand, he to 71152 thousand hectare during the same period. It represents $85.22 \%$ increase in total operated area of small holdings with an annual growth rate of $2.43 \%$. 
The operational area of medium holdings has declined from 82,056 thousand ha in 1976-77 to 71,533 thousand ha in 2010-11 i.e., ratio of medium holdings in total operational area has decreased from $50.24 \%$ to $44.82 \%$ during the same period, this shows- $-12.82 \%$ decrease with an annual growth rate $-0.37 \%$.

Similarly the percentage share of large holdings in total operational area of the country is also reduced from $26.25 \%$ to $10.59 \%$ during 1976-77 to 2010-11, decline in operational area of large holdings to 16,907 thousand ha in 2010-11 from 42873 thousand he in $1976-77$. It also shows $-60.56 \%$ decline in operational area of large holdings with an annual growth rate $-0.07 \%$.

Therefore, there is positive trend in small holdings and negative change in medium and large holdings operational area. Not only in the ratio, but in absolute terms also there is continuous increase in operational area of small holdings and continuous decrease in operational area of medium and large holdings during 1976-77 to 2010-11.Therefore, as per Agricultural Census of 2010-11 the ratio of small holdings account for $85.01 \%$ of total holdings with $44.58 \%$ of total operational area and the corresponding figures were $72.64 \%$ and $23.52 \%$ in $1976-77$.

Table 5。 Trends in average size of holdings in India (in ha)

\begin{tabular}{lrrrrr}
\hline Size groups & $1976-77$ & $1985-86$ & $1995-06$ & $2005-06$ & $2010-11$ \\
\hline Small & 0.65 & 0.64 & 0.63 & 0.61 & 0.61 \\
Medium & 4.13 & 3.96 & 3.76 & 3.63 & 3.62 \\
Large & 17.57 & 17.21 & 17.21 & 17.08 & 17.38 \\
All sizes & 2.00 & 1.69 & 1.41 & 1.23 & 1.15 \\
\hline
\end{tabular}

Source: GOI, Agricultural Census Reports from 1976-77 to 2010-11, Ibid

Table 5 reveals that as the average size of land holdings in India decreases, the average size of small, medium and large holdings also decreases. The average size of small holdings was 0.65 ha in 1976-77 which decreased to 0.61 ha in 2010-11.

The average size of medium holdings decreased from 4.13 he to 3.62 ha, and average size of large holdings also decreased from 17.57 ha to 17.38 ha during 1976-77 to 2010-11. Compared to the decrease in average size of all holdings, the reduction in average size of different size holdings is less.

As said earlier the ratio of number of small holdings in total number of land holdings in India is $85.01 \%$ but it is in the range of $15.03 \%$ to $98.96 \%$ in different states and union territories. The $85.01 \%$ ratio of small holdings among number of holdings in the country in 2010-11 is not similar in the states and union territories. It is maximum in Kerala (98.96\%) followed by Lakshdweep (98.41\%) and minimum in Nagaland (15.03\%) followed by Punjab (34.19\%). In total operational area the ratio of small holdings is $44.58 \%$ with the range of $2.46 \%$ to $80.72 \%$ in different states and union territories. It is maximum in West Bengal (80.72\%) followed by Kerala $(77.31 \%)$ and minimum in Nagaland(2.46\%) followed by Punjab (9.33\%).

The lowest ratio of small holdings in number and operational area is in Nagaland state in 2005-06 and 2010-11, also with highest average size of holdings i.e., 6.93 ha and 6.92 ha during the same period. The ratio of small holdings in number is $75 \%$ and above is, in 26 states/Union territories, out of 34 in 2005-06, and in 27 states/Union territories out of 35 in 2010-11. Similarly, the share of small holdings in operational area is less than 50\% in 18 states $2005-06$ and 2010-11.

The average size of land holdings in India in 2010-11 was 1.15 ha and it is minimum in Kerala ie., 0.22 ha in 2010-11 and 0.23 ha in 2005-06 followed by Lakshadweep ( 0.27 ha in 2010-11 and 2005-06)and maximum in Nagaland i.e., 6.02 ha in 2010-11 and 6.93 ha in 2005-06 followed by Punjab (3.77 ha in 2010-11 and 3.95 ha in 2005-06).

Similarly the average size of small holdings was 0.61 ha both in 2005-06 and 2010-11. It is lowest in Kerala (0.17 he in 2005-06 and in 2010-11), followed by Lakshdweep (0.21 ha in 2005-06 and in 2010-11). Similarly it is highest in Punjab (1.03 ha in 2010-11 an 1.08 ha in 2005-06 ha) followed by Nagaland (0.98 ha in 2010-11) and Gujarat (0.94 ha in 2005-06).

\subsection{Small Farms and Their Strengths-The Indian Scenario}

5.3.1 Nature of Land Holdings 
Table 6. Net sown area of different size holdings in India

\begin{tabular}{lrrrr}
\hline \multirow{2}{*}{ Years } & \multicolumn{2}{c}{ Net area sown ( in 'ooo ha) } \\
& Small & Medium & Large & All size holdings \\
\hline \multirow{2}{*}{$1976-77$} & 32673 & 66193 & 29678 & 128544 \\
& 86.65 & 83.22 & 73.63 & 81.59 \\
$1986-87$ & 36590 & 67677 & 21082 & 128354 \\
& 82.43 & 86.75 & 82.13 & 86.68 \\
$1996-97$ & 42615 & 57273 & 16565 & 116451 \\
& 91.38 & 89.35 & 81.71 & 88.89 \\
$2006-07$ & 49518 & 54655 & 12427 & 116599 \\
& 91.93 & 89.03 & 79.53 & 89.09 \\
\hline \%of variation & 51.66 & -17.43 & -58.13 & -9.29 \\
(1976-77 to 2006-07) & & & \\
\hline
\end{tabular}

Source: GOI, Input Survey Reports from 1976-77 to 2006-07, All India Report on Input Survey, Agricultural Census Division, GOI, New Delhi

Table 6 reveals the net area sown out of operational holdings, which is more in small holdings compared to medium and large holdings. The proportion of net area sown in operational area of holdings is more in case of small holdings compare to medium and large holdings during 1976-77 to 2006-07 shows there is an intensive use of land by small holders. There is $51.66 \%$ increase in net area sown of small farms, but there is decrease of $-17.43 \%$ and $-58.13 \%$ in net area sown of medium and large holdings during the same period.

5.3.2 Access to Irrigation

Table 7. Net Irrigated area of different size holdings in India

\begin{tabular}{lrrrr}
\hline \multirow{2}{*}{ Years } & \multicolumn{3}{c}{ Net irrigated area ( in 'ooo ha) irrigation ratio to netarea sown in \% } \\
\cline { 2 - 5 } & Small & Medium & Large & All size holdings \\
\hline \multirow{2}{*}{$1976-77$} & 11031 & 15113 & 3693 & 29837 \\
& 33.76 & 22.83 & 12.44 & 23.21 \\
$1986-87$ & 15730 & 20544 & 4901 & 41179 \\
& 39.73 & 30.36 & 23.25 & 32.08 \\
$1996-97$ & 21636 & 24602 & 5191 & 51428 \\
& 50.77 & 42.96 & 31.34 & 44.16 \\
$2006-07$ & 24605 & 25116 & 4775 & 54496 \\
\% variation (1976-77 to & 49.69 & 45.95 & 38.42 & 46.74 \\
2006-07) & 123.05 & 66.19 & 29.30 & 82.65 \\
\hline
\end{tabular}

Source: GOI, Input Survey Reports from 1976-77 to 2006-07,Ibid

There is an increase in access to irrigation among all size land holdings as seen in Table 7. The irrigation ratio to net area sown is greater in small farmers from 1976-77 to 2006-07. The increase in irrigation ratio is also more in case of small farmers compared to medium, large and all size farmers i.e., $123.05 \%, 66.19 \%, 23.30 \%$ and $82.65 \%$. The use of cheaper source irrigation like canals is greater in large farmers compared to small farmers i.e., $40 \%$ and $25 \%$ respectively (NCEUS, 2008).

\subsubsection{Cropping Intensity}

Table 8. Cropping Intensity according to farm size class in India

\begin{tabular}{lrrrr}
\hline Year & Small & Medium & Large & All size holdings \\
\hline $1976-77$ & 126 & 116 & 108 & 117 \\
$1986-87$ & 131 & 121 & 116 & 123 \\
$1996-97$ & 137 & 130 & 123 & 131 \\
$2006-07$ & 136 & 126 & 125 & 130 \\
\hline \% variation & 7.94 & 8.62 & 15.74 & 11.11 \\
\hline (1976-77 to 2006-07 & & & \\
\hline
\end{tabular}

Source: GOI, Input Survey Reports from 1976-77 to 2006-07,Ibid 
Table 8 indicates that, the multiple cropping index is higher for small farmers than that for medium and large farmers. But increase in cropping intensity for small farmers is 126 to 136 but is lower compared to medium and large farmers during 1976-77 to 2006-07.

\subsubsection{Irrigation Intensity}

It is crucial indicator reflecting effective gross availability of water per unit area of cultivable land. There is greater increase in the ratio of gross irrigated area to net irrigation area in case of small farms i.e., 1.19 to 14.29 during 1976-77 to 2006-07. But, increase in irrigation intensity for small farmers is greater than medium and all size holdings, but less than large holdings. Similalry, the ratio of irrigation intensity is same with little variation among different size of holdings during the same period.

\subsubsection{Access to Fertilisers and HYV Seeds}

The fertiliser per hectare is inversely related to farm size for irrigated and unirrigated areas. It got increased from 110 $\mathrm{kgs}$ to $183 \mathrm{kgs}$ per hectare in case of small farmers during 1976-77 to 2006-07. By medium farmers it got creased from $103 \mathrm{kgs}$ to $129 \mathrm{kgs}$ per hectare and it is decreased in case of large farmers from $93 \mathrm{kgs}$ to $85 \mathrm{kgs}$ per hectare during the same period. Use of fertiliser per hectare by small farmers has increased faster in irrigated areas than unirrigated areas.

Similarly the percentage of holdings used HYV is also inversely related to farm size. The ratio of use of HYV is more than $75 \%$ in case of small farmers during 1996-97 to 2006-07. The use HYV is very less among large holdings. Therefore, small holdings in India have been found using higher doses of inputs.

\subsubsection{Area Treated with Fertiliser and Farm Yard Manure}

The ratio of area treated with fertiliser is more in irrigated holdings than unirrigated holdings of all size holdings. There is faster increase in area treated with fertiliser by small farmers in irrigated and unirrigated holdings ie., $68.35 \%$ to $93.82 \%$ and $21.01 \%$ to $56.65 \%$ respectively compared to medium and large holdings. According to $2006-07$ Input Survey, the ratio of area treated with fertiliser is more among small farmer both in irrigated and unirrigated holdings.

Similarly, the area treated with use of farm yard manure is lower ie., 20 to 30\%compared to use of fertiliser. The use of farm yard manure is more in unirrigated holdings rather than irrigated holdings of small farms. And proportion of use of farm yard manure is also more in case of small farmers compared to medium and large farmers.

\subsubsection{Cropping Pattern \&Diversification}

As per agricultural census of 2005-06 there is greater proportion of cereals followed by pulses in gross cropped area of different size holdings. Among different size holdings small farms prefer to production of cereals followed by pulses. In the view of transformation small holders"e agriculture in India, Birthal et al (2011) provide four conclusions regarding cropping pattern among different size of land holdings. They are: a)Small farmers allocate larger proportion of their cultivated land to high value crops like fruits and vegetables b) Small farmers seem to have comparative advantage in growing vegetables than fruits because of quick returns c) Small farmers allocate larger proportion of rice and wheat than other farmers d) Small farmers allocate lower proportion of land to pulses and oilseeds.

\subsubsection{Farm Size, Output and Productivity}

Table 9.Value of output per hectare (Rs.)

\begin{tabular}{lll}
\hline Marginal \&Small holdings & Medium \&Large holdings & All size holdings \\
\hline 13944 & 11333 & 12535 \\
\hline
\end{tabular}

Source: GOI 2005, Situation Assessment Survey of Farmers: Some Aspects of Farming -2003 and Mahendra Dev. S (2011).

There is greater contribution to the output by marginal and small farmers compared to their share in area. The NSS 2003 farmers survey has empirically proved the inverse relation between farm size and productivity. Table 9 shows the small farms produce which is more in value terms per hectare (Rs. 13,944) than medium and large farms (Rs. 11,333), which proves that small farms are more efficient than other farms. Form the NSS report it is found that the share of these farmers was $46.1 \%$ in operational area, but $51.2 \%$ contribution is to the total output of the country during 2002-03. It is true in majority of states of India. The contribution to the output by small farmers ranges from $19 \%$ in Punjab to $86 \%$ in West Bengal.

There is greater contribution by small farmers in the production of high value crops also. Birthal et al (2011), states that small farmers contribute $70 \%$ to total production of vegetables, $55 \%$ to fruits against their share of $44 \%$ in land area. Their contribution in cereal production is $52 \%$ and $69 \%$ in milk production. Therefore, small farmers are responsible for diversification and food security of the country. Their share is lower in case of production of pulses and oilseeds. 


\subsubsection{Food Security}

Small farms also contribute to greater food security, particularly in area with poor infrastructure where high transport costs make locally produced foods less costly. Small farms also spend greater portion of their incremental income on locally produced goods and service, thus it helps to stimulate employment opportunities in the local and rural non farm economy.

\subsubsection{Use of Improved Technology}

The reports of Input survey on farmer also provide the advantages of small farms, as small holders have adopted new technology on much larger scale compared to large farm holdings. The emerging changes in labour market and the rising demand for labour will further increase advantage of small holders over large size holdings. The much vaunted scale advantage has not provided any edge to large size holdings nor has it constrained production in small holdings.

\subsection{Small Farms Productivity and Livelihoods}

As stated above there is predominance of small farm holders in Indian agriculture, as their share in total holdings is $85 \%$. The sustainability of small farms is crucial for livelihoods in rural area and for the entire country. The above stated factors related to the issues and role of small farms reveals that, as lower the size of holding, higher is the use of inputs, crop intensity and irrigation intensity, coverage of HYVs and making more intensive use of land and use new technology on a larger scale. Certainly, the greater use of these factors helps to higher productivity in small farms. This inverse relation is not diluted with advancement of technology or modernisation of agriculture. The number of reports which provide information related to structure of land holdings, cropping pattern, input use and other related aspects of land holdings in India viz., reports of Agricultural Census, Input survey, the RBI, the CSO etc. But the information of farm size and productivity is available only from the reports of $59^{\text {th }}$ round NSS report on assessment of farmers during the year 2002-03.In this report, the value of output per hectare of different size classes is calculated by dividing the value of output per household by average size of holding.

Table 10. Agricultural productivity per household, per hectare and per capita of different size holdings

\begin{tabular}{lrrrrr}
\hline \multirow{2}{*}{ Farm size (ha) } & \multirow{2}{*}{$\begin{array}{c}\text { Household } \\
\text { size (No.) }\end{array}$} & \multirow{2}{*}{$\begin{array}{c}\text { Per capital land } \\
\text { (ha) }\end{array}$} & & \multicolumn{3}{c}{ Output value (Rs.) } \\
\cline { 5 - 6 } & 5 & 0.04 & 4,783 & 965 & 25,173 \\
\hline 0.01 to 0.4 & 5 & 0.12 & 12,563 & 2,364 & 1,892 \\
0.4 to 1 & 6 & 0.24 & 23,292 & 3,801 & 16,780 \\
1.01 to 2 & 6 & 0.43 & 40,403 & 6,734 & 15,091 \\
2.01 to 4 & 7 & 0.82 & 77,120 & 10,588 & 13,564 \\
4.01 to 10 & 8 & 2.20 & $1,37,473$ & 16,782 & 7,722 \\
$>10$ & 6 & 0.22 & 18,858 & 3,143 & 15,426 \\
All size & 6 & &
\end{tabular}

Source: GOI 2005, Situation Assessment Survey of Farmers: Some Aspects of Farming -2003 and Chand et al., (2011).

Table 10 states the results of the reports which indicate the inverse relation between farm size and land productivity. The value of per hectare output is comparatively greater in case of holdings less than 2 hectare, than holdings of greater than 2 hectare. The value of output per hectare of medium farms and large farms is half of and one third of value of output of small farms respectively.

Table 11.Value of output-net farm income and cost of cultivation of small farms

\begin{tabular}{lcrr}
\hline Income/cost & $\begin{array}{r}\text { Small holdings } \\
(\text { less }<2 \text { ha })\end{array}$ & $\begin{array}{r}\text { Holdings } \\
(\text { more }>2 \text { ha }\end{array}$ & $\begin{array}{r}\text { All size } \\
\text { holdings }\end{array}$ \\
\hline Value of output per hectare (Rs.) & 13,944 & 11,333 & 12,535 \\
Cost of cultivation per hectare (Rs.) & 6,530 & 5,252 & 5,841 \\
Net Farm income per hectare (Rs.) & 7,414 & 6,080 & 6,694 \\
\hline
\end{tabular}

Source: GOI 2005, Situation Assessment Survey of Farmers: Some Aspects of Farming -2003

Table11 shows that value of output per hectare and net farm income per hectare of cropped area is greater for small farms than medium and large farms. Similarly, the table also reveals that the cost of cultivation per hectare of small holdings is also greater than medium and large holdings. 
The per capita output is low on smallholdings despite higher productivity (Chand et al 2011), due to lower per capital availability of land. Therefore, tiny piece of land cannot generate enough income to take care of the livelihood needs of a small farm family. According to Tendulkar Committee norm, for the family dependent on agriculture income, there is need of a minimum 0.8 ha of land area, which is needed to keep a farm family above the poverty line.

Therefore, $3 / 4$ of smallholders"e population cannot meet their livelihood from farm income alone. NCEUS (2008) also reveals that the poverty for small holdings farmers is much higher than other farmers. There is need to increase productivity and income of small holdings and to promote non-farm employment opportunities for these farmers.

\subsection{Productivity of Small Farms-Constraints and Challenges Faced by Small Holdings}

The inverse relationship between size and productivity of farms has been questioned on grounds of variation in soil quality. The assumption of inverse relationship of size of farms and productivity becomes invalid when soil variation is considered. The inverse relationship leased to hold in more dynamic zones. With the advances in the technology the inverse relationship would vanish (Chadha, 1978). The productivity of small farms is largely due to desperate struggle of poor peasants for survival on below subsistence plots of land (Dyer, 1997). Small farming does not alleviate poverty and create employment opportunities. Over intensive cultivation of small farms may result in exhaustion of soil productivity. The advantages of small holders disappear as countries develop. As per capital income rises, the economy diversifies and workers leave agriculture and the wage rate goes up (Hazell, 2011). It then becomes more efficient to have progressively larger and more mechanised farms.

Despite their significance in providing food security, family labour employment and economy in management and high productivity per acre, small farms face a few challenges particularly in the wake of globalisation and WTO dispensation. Following are the major challenges faced by small farm.

\section{Constraints and Challenges for small farmers}

One of the paradoxes of the Indian economy is that decline in the share of agriculture and allied activities in occupational structure and GDP. But decline in share of agricultural workers is slower than decline in share of agriculture in GDP. The occupational share of agriculture declined from $72.1 \%$ in 1950-51 to 53.02\% in 2013 (FA0 2014). But there is sharp decline in share of agriculture and allied activities in GDP from $51.88 \%$ in $1950-51$ to $13.69 \%$ in 2012-13, at 2004-05 prices. Similarly, the share of agriculture in GDP declined from $41.83 \%$ to $11-65 \%$ during 1950-51 to 2012-13, at 2004-05 prices. As stated earlier there are 138 million landholdings in India, out of them 118 million holdings belong to small farmers. They constitute $85 \%$ in land holdings and $45 \%$ in total operational area in the country. Hence, the average size of holdings in India declined to 1.15 ha and the average size of small holdings is 0.61 ha. The growth rate of agriculture and allied activities declined from 3.48\% to 1.91\% from 1950-51 in 2012-13. Similarly, the growth rate of agriculture in GDP got declined from $3.83 \%$ to $1.72 \%$ in $2012-13$ at 2004-05 prices and it is some time negative also. With tiny piece of land, small farmers have number of constraints and challenges to manage their livelihood and food security of the country.

There are many issues and challenges for small holdings agriculture in India. NSS Farmers"e survey 2003 reported number of issues related to small and marginal farmers. Based on this report, NCEUS(2008)states the common issues which concern the small farmers, they are: imperfect markets for inputs/product leading to smaller value realisations,; absence of access to credit markets or imperfect credit markets leading to sub-optimal investment decisions or input applications; poor human resource base; smaller access to suitable extension services restricting suitable decisions regrading cultivation practices and technological know-how; poor access to public goods such as public irrigation, command area development, electricity grids; greater negative externalities from poor quality land and water management etc. Apart from these, some other issues and challenges relating to small farmers are as follows:

\subsubsection{Declining Size of Holdings}

Due to increasing number of land holdings and decreasing area of operational holdings there is declining per capita arable land in India. Therefore, it is difficult for small farms to become viable economic units especially in rainfed conditions.

\subsubsection{Parcels of Land Holdings}

Fragmentation of holdings in Indian agriculture has always been a serious bottleneck in increasing agricultural productivity. As per 2006-07 Input Survey the number of parcels per holding is 1.87 in case of small farmers and 2.22 for all size holdings. Therefore, area per parcel per holdings will be minimum, it is 0.35 ha and 0.59 ha for small and all size holdings respectively.

\subsubsection{Social Groups}


The proportion of socially disadvantaged groups such as Scheduled Castes and Scheduled Tribes is higher among small farmers than that of medium and large farmers. Even after accounting for quantity and quality of land owned by socially deprived classes, their access to information, marketing, credit and publicity provided inputs and extension services are lower. This shows that they possibly suffer from discrimination in the delivery of public services as well as market (NCEUS, 2008)

\subsubsection{Land and Tenancy Security}

Due to small size of landholding the small farmers are compelled to augment their operational area through tenancy or leasing-in land. Most tenants are landless or small landholders. Tenancy is not documented and remains founded on verbal contracts of cost and crop sharing. The informal tenurial system will be the cause for less intensive use of labour and other inputs, slower adoption of technology, lower investment for land improvement, leading to low levels of output. With no documentary-proof tenants will also be unable to access institutional credit and approach money lenders for purchase of inputs. By land reforms they own and cultivate some land but it is a limiting factor for getting resources. There is a need of tenancy security for small farmers.

\subsubsection{Credit and Indebtedness}

Small farmers are at disadvantage in accessing credit. Small farmers require a credit package covering production, investment and consumption, some credit for repayment of previous debts. But such packages are not available to them in formal credit markets. Unregistered cultivators, tenants and tribal cultivators face difficulties to access institutional credit and other facilities available to farmers with land titles.

\subsubsection{Globalisation Challenges}

Increasing globalisation has added to the problems of small farmers. Small farmers are facing inherent disadvantages with increasing market integration and globalisation. Among the most powerful forces working against the small farmers are - competition from other countries in respect of price, quality, nature of products, shift towards consumer-driven market, demand much more in terms of quality and food security etc.

\subsubsection{Demand for High Value Agricultural Commodities}

Due to urbanisation, rising incomes, diet conscious, increased participation of women in urban jobs, impact of globalisation, etc, there is changing lifestyle of middle class households; there is higher demand for fruits, vegetable, milk. meat, egg, fish and sugar than food grains. Small farmers have the potential to raise their incomes by switching from grain based production system to high value agriculture products. Even though the production of high value agriculture products is labour intensive and more suitable for small holders, it has number of constraints like perishability, fragmented market, high variations in prices, etc. Therefore, smallholders face high transaction costs and risks in production and marketing such commodities.

\subsubsection{Increasing Demand for Processing Foods}

Small farmers are often forced to sell their surpluses at low prices or under stress sale. There is need of post harvest processing and value addition at farm level viz., fruit pulp making, pickle making, preservation of vegetables, etc.

\subsubsection{Impact of Climate Change}

It is a major challenge for agriculture, food security and rural livelihoods in India. It s $^{\circ}$ adverse effect is more on small farmers. They are facing crop failure, loss of livestock and lives also.

\subsubsection{Water Shortage and Water Management}

The demand for water for agricultural and non-agricultural uses in rising, and water scarcity is becoming acute and it is limiting the future expansion of irrigation. Lack of water resource and inefficient water management etc., are becoming constraints for productivity of small holders by soil salinity and waterlogging. Small holdings are depending more on ground water compared to larger holdings but ground water is depleting in many parts of India.

\subsubsection{Input Supply Constraints}

Small farmers are facing lack of access to inputs, inadequate availability, lack of quality inputs, non availability in affordable packages, lack of timely support, lack of knowledge and lack of location specific and small farmer friendly technologies. Subsidies on agricultural inputs compensate the poorest farmers to a small extent only, as they use few purchased inputs and underpricing of fertiliser causes overuse of subsidised nutrients and imbalance in NPK ratios.

\subsubsection{Poor Access to Public Goods}

Poor access to ,public goodse such as public irrigation command area development, electricity grids, greater negative externalities from poor quality land and water management. 


\subsubsection{Low Level of Formal Education and Skills}

NSS reports on farmers and employment, and Input Survey shows that literacy and mean years of education are lower for small holding farmers, compared to medium and large farmers. There is less awareness among small farmers regarding bio-fertilisers, minimum support prices etc. Therefore, there is need for small farmers i.e., a reasonable level of awareness regarding information of agriculture.

\subsubsection{Unorganised Small Farmers}

There is poor bargaining capacity among small farmers as they are scattered, unorganised, less educated, and ignorant.

\subsubsection{Risk and Vulnerability}

Small farmers face number of risks at individual and household level, viz., health hazards- disease, injury-accidents-disability, employment and unemployment risks, injury and death of animals and common risks like drought, epidemic and economy wide shocks etc., leading malnutrition, disease, starvation, deaths, indebtedness, sale of assets, spending from saving, child labour, bonded labour, reduction of consumption and migration.

5.5.16 Poor access to suitable extension services restricting suitable decisions regarding cultivation practices and technological know how.

Therefore, small farmers typically face number of problems and challenges. If more small farmers are to have a viable future, there is need for a concerted effort by government and private sector enabling economic environment for their development. How to create more entrepreneur farmers?

\section{Discussion}

In spite of the challenges, there are many technological and institutional innovations which can enable small farmers to raise agricultural productivity and increase incomes through diversification and high value agriculture. The opportunities are created through research and extension for small farming. Technological innovations leading to better opportunities for small holdings involve:

- Zero tillage

- Public sector-led improved technologies

- Nutrient management

- $\quad$ Bio technology

- Institutional innovations involve-land and water management-institutions like water user associations for water management of canal irrigation.

- Small farmers have the potential to raise their incomes by switching from grain based production system to high value agriculture.

Small farmers should be empowered by enhancing their access to production resources (land, water, energy and credit), appropriate technologies and skill development opportunities, information, fair market for products and inputs, healthcare and sanitation and most importantly to education and productive social services. There is need for diversification as a strategy to achieve output growth, employment generation and natural resources sustainability.

Small farmers have tremendous scope for increase in productivity because of natural capital such as soil; the water for bio-diversity can be enhanced through conservation and rejuvenation. Small farmer can intensify bio-diversity, and higher the bio-diversity the higher the productivity and stability and sustainability of agriculture.

It is essential to strengthen marketing chains and quality standards and enabling small farmers to have greater access to credits and grants in order to make them viable, especially in the face of tougher international competition. It is expedient to induct innovation in the management of small farms which needs creation accumulation, sharing and use of knowledge. The involvement of farmers in this process is key in building their capacity so that they can seek knowledge either in the form of information or new findings and process it into innovation.

It is necessary to make more concerted and integrated efforts to bridge the gap between technology generated and affordability of smallholders by generating appropriate low cost water saving technologies and to promote awareness among the farmers about generating and use of already available irrigation techniques suitable for different types of crops.

\section{Conclusion}

The intense debate about the relationship between farm size and productivity has largely conformed to the view, that small holdings in India in agriculture exhibit a higher productivity than large holdings. The inverse relationship between farm size and productivity based on the aggregate of all crops has been quite pronounced in recent years. The findings 
of National Sample Survey and other research have been quite supportive of this conclusion. It has been concluded by various research studies that advances in technology and the scale factor in production did not dilute the superior performance of small size holdings.

\section{References}

Bardhan, P. K. (1973). Size, Productivity and Returns to Scale-An Analysis of Farm Level Data in Indian Agriculture. Journal of Political Economy, 81(6), 1370-86. http://dx.doi.org/10.1086/260132

Berry, R. A. (1972). Farm Size, Distribution, Income Distribution and the Efficiency of Agricultural Production. Colombia-American Economic Review, 62(2), 403-08.

Birthal, P. S., Joshi, P. K., \& Narayanan, A. V. (2011). Agricultural Diversification in India: Trends, contribution to growth and small farmer participation. A discussion paper 00814 of INCRISAT.

Chadha, G. K. (1978). Farm Size and Productivity Revisited-Some Notes from Recent Experience Of Punjab. Economics and Political Weekly, XIII(39),September.

Chand, R., L., Prasanna, P. A., \& Sing, A. (2011). Farm Size and Productivity-Understanding the Strength of Small Holders and Improving their Livelihood. Economic and Political Weekly, XLVI(26\&27), June.

Dev, M. S. (2011). Small Farmers in India: Challenges and Opportunities. Paper presented at Emerging Economies Research Dialogue. Organised by ICRIER. Beijing, China, 14-15 November.

Dixon, J. K, Taniguchi., \& Wattenbach.(Eds) (2003). Approaches to Assessing the Impact of Globalisation on African smallholders: Household and village economy modelling. Proceedings of a working session on Globalisation and the African Smallhodler Study. FAO and World bank, Rome-FAO of UN.

Dyer, G. (1997). Class, State and Agricultural Productivity in Egypt-A Study of Inverse Relationship Between Farm Size and Land Productivity, London. Frank loss publishers.

Evans, R. (Eds) (2011). New green farming vital to end global hunger: U.N, Geneva. Available at http://www.reuters.com

FAO (Food and Agiculture Organisation of the United States), 2014, FAO data book, FAO Statistics Division.

Government of India. All India Reports on Number and Area of Agricultural Holdings from 1976-77,1980-81,1990-91,2000-01,2005-06 and 2010-11.Agriucltural Census Division, Department of Agriculture and Co-operation, New Delhi.

Government of India. (2005). Situation Assessment Survey of Farmers: Some Aspects of Farming-2003. Reports of NSS $59^{\text {th }}$ Round (January-December 2003), Report No. 496(59/33/3). Ministry of Statistics and Programme Implementation.

Government of India. (2013). Agricultural at a glance 2013. New Delhi. Ministry of Agriculture, Department of Agriculture and Co-operation.

Government of India. (2013). Agricultural Situation in India- February 2013. New Delhi. Directorate of Economics and Statitstics, Department of Agriculture and Co-operation.

Government of India. Reports on Input Survey from 1976-77, 1986-87, 1996-97 and 2006-07, Agriucltural Census Division, Department of Agriculture and Co-operation, New Delhi.

Hanumanth, R. (1966).Alternative Explanation of the Inverse Relationship Between Farm Size And Out Per Acre in India. Indian Economic Review, 1(2).

Hazel, P. (2011). Five Big Questions About Five Hundred Million Small Farms. Key note paper presented at the Conference on New Directions for Small Holder Agriculture, IFAD. Rome, 24-25 January 2011.

Hazel, P. (2011). Five Big Questions About Five Hundred Million Small Farms. Key note paper presented at the Confidence on New Directions for Small Holder Agriculture, IFAD. Rome, 24-25 January 2011.

Hazell, P. C., Poulton, S., Wiggins \& Dorward, A. (2007). The Future of small farms for poverty reduction and growth. Discussion Paper 42-2020: Washington D.C: International Food Policy Research Institute (IFPRI).

Khusro, A. M. (Ed). (1968). Returns to scale in Indian Agriculture-Reading in Agricultural Development, New Delhi, Allied publishers.

Lipton, M. (2005). The Family Farm in a Globalising World: The Role of Crop Science in Alleviating Poverty.2020 vision for Food, Agriculture and the Enviornment Initiateve. Discussion Paper 40, Washington DC; IFPRI.

Muzumdar, D. (1965). Size of Farm and Productivity -A Problem of Indian Peasant Agriculture-Economics. Economica, 
32(May), 161-173. http://dx.doi.org/10.2307/2552546

Narayanan, S., \& Gulati, A. (2002). Globalisation and the Smallholders: A Review of Issues, Approaches and Implications. Markets and Structural studies Division Discussion paper No.50, Washington D.C:IFPRI.

NCEUS (The National Commission on Enterprises in the Unorganized Sector). (2008). Report on A Special Programme for Marginal and Small Farmers. New Delhi. National Commission for Enterprises in the Unorganised Sector. available at www.nceus.gov.in

Saini, G. R. (1971). Holdings, Size Productivity and Some Related Aspects of India Agriculture. Eonomic and Political Weekly, VI(26), 79-85.

Sen, A. (1962).An Aspect of Indian Agriculture. Economic Weekly, Annual Number, February, 243-246.

Sen, A. (1964). Size of Holdings and Productivity, Economic Weekly, Annual Number, February, P-323.

Thapa, G. G., \& Gaiha, R. (2011). Smallholder farming is Asia and the Pacific: Challenge and Opportunities. Paper presented at the Conference on New Directions For Small Holder Agriculture, IFAD. Rome, 24-25 January 2011.

Vandana, S. (2007). India Needs Her Small Farmers. Counters Currents.Org, April. www.countercurrents.org

World Bank. (2003). Reaching the Rural Poor-A Renewed Strategy for Rural Developmet. Washington DC.

\section{$(\mathrm{cc}) \mathrm{BY}$}

This work is licensed under a Creative Commons Attribution 3.0 License. 